\title{
EFFECT OF CONSANGUINITY ON CONGENITAL DEFECTS
}

\author{
Sundip Hemant Charmode ${ }^{1}$
}

\section{HOW TO CITE THIS ARTICLE:}

Sundip Hemant Charmode. "Effect of Consaguinity on Congenital Defects". Journal of Evolution of Medical and Dental Sciences 2015; Vol. 4, Issue 43, May 28; Page: 7461-7471, DOI: 10.14260/jemds/2015/1083

ABSTRACT: CONTEXT/BACKGROUND: Congenital malformations have been known and recognized for centuries. It is a stimulating problem for research because of the high frequency of their occurrence and the influence of consanguinity on these defects is even more devastating problem. AIM AND OBJECTIVES: To determine the effect of consanguinity in occurrence of congenital defects and occurrence of more common types of congenital defects. MATERIALS AND METHODS: The study was done retrospectively in Government medical college and civil hospitals between $1^{\text {st }}$ Oct. 2011 till 31st May 2012. A total of 182 congenitally defective live births and still births admitted in above hospitals in same period were studied against total deliveries taken place. Information was collected by using questionnaires and pedegree charts were formed. Information about consanguinity, degree of consanguinity, type and subtype of anomaly etc. was obtained. Data obtained was statistically analysed and compared with previous studies. RESULTS: Incidence of congenital anomalies was $1.16 \%$. Cardiovascular defects were the most common type of anomaly and atrial septal defect was most common subtype. Third degree / first cousins was the most common type of degree of consanguinity found amongst all. Male pre-ponderence was found amongst the anomalous births. Frequency of consanguineous marriages was found more in muslims than hindus. DISCUSSION AND CONCLUSIONS: 1. Births with congenital defects were commonly occurring among normal births and the incidence calculated was $1.79 \%$ in the present study. 2 . Cardiovascular defects were most common type of defects. 3. In the present study, it was found that third degree consanguinity cases were most common, about $56.25 \%$ out of all 48 consanguineous cases. 4 . In the present study congenital defects were found to occur more commonly in consanguineous unions than non- consanguineous unions.

KEYWORDS: Consanguinity, Congenital defect, Congenital anomaly, Congenital malformation, Consanguineous marriage.

INTRODUCTION: India is composed of thousands of subpopulations divided by geography, language, religion and caste. ${ }^{1}$ Consanguineous marriage is widely practiced here with reasons given are geographic, settling economic or inheritance problems, prospective mates knowing each other well, he (or she) is the only possible mate. ${ }^{2}$ Consanguinity means" blood relation", derived from the Latin word" consanguinitas". A consanguineous marriage is defined as a union contracted between persons / couple biologically related as second cousins or closer, equivalent to coefficient of inbreeding in the progeny of $r \geq 0.0156$. Globally, the most common form of consanguineous union contracted is between first cousins. ${ }^{3}$

The highest rates of consanguineous marriage occur in north and sub-Saharan Africa, the Middle East, and west, central, and south Asia. ${ }^{4}$ From a genetic perspective, consanguineous marriage increases the chances that both members of the union will carry recessive variants passed through the family, which increases the chance that their offspring will be affected by a recessive disease. ${ }^{5}$ 


\section{ORIGINAL ARTICLE}

Various defects show significant effect of consanguinity like Club foot, Polydactyly, syndactyly, Oligodactyly, Dysplasia of acetabulum, Atresia ani, Harelip with or without cleft palate, Simple cleft palate, Anencephalus, Anophthalmus and microphthalmus, Hydrocephalus. ${ }^{6}$

MATERIALS AND METHODS: The present study is retrospective in nature and conducted in Government medical college and hospital in western Maharashtra. Before starting the study prior permission of the Professor and Head of department of Anatomy, Obstetric and Gynaecology and Paediatric faculties of college mentioned above was taken. Approval of ethical committee was acquired before starting the study.

182 new births with congenital defect of any system of human body born in or referred to the above hospitals including stillbirths and abortions during the period between $1{ }^{\text {st }}$ October 2011 till $31^{\text {st }}$ may 2012 were included in the study.

At the time of birth or referral whatever was the outcome of conception i.e. abortion, intrauterine death, live birth, neonatal death, stillbirth with any congenital malformation was termed as Proband.7

Before taking the history, Informed consent of proband's parents was taken using the consent form and the information was kept confidential.

Patient's history was recorded using the proforma / questionnaire especially designed for the study in Marathi and English by meeting the parents of proband in person. The proband of which the history was insufficient and in which the follow up of their parents could not be done were removed from the study.

The proforma/questionnaire for history taking included detailed information regarding type of congenital defect and associated defects, subtype of defect, history of consanguineous relationship between the parents and degree of consanguinity. Pedigree charts were prepared in all the cases.

The cases were classified depending upon the type and subtype of the congenital defect. Proband's were also divided based on all the variables mentioned earlier.

Degree of Consanguineous marriage was categorized into First degree i.e between first degree relatives i.e, between father and daughter, mother and son, between siblings; Second degree i.e between Second degree relatives like uncle -niece, nephew- aunt, half sibling; Third degree between third degree relatives like first cousins, half uncles and half niece, half aunt and half nephew. ${ }^{8}$

Data obtained in respect with all the variables was tabulated and shown by using Bardiagrams and Pie chart.

Comparison of the occurrence of congenital defect was done with presence of consanguineous relationship in parents, degree of consanguinity of parents. The findings were then statistically analysed using Pearson chi-square test and" p value" determined. Statistical significance of that finding was mentioned below each table.

The findings were then discussed with other comparable studies done previously by authors within or outside India and final conclusions were drawn from the present study.

OBSERVATIONS AND RESULTS: It was found that during the period between 1 st October 2011 and 31 $1^{\text {st }}$ May 2012, total deliveries taking place in Government medical college and both civil hospitals were 10,114 including (Normal and caesarean section) and total admissions of anomalous births in the NICU were 182 hence incidence of congenital defects calculated was $1.79 \%$. 


\section{ORIGINAL ARTICLE}

\begin{tabular}{|c|c|c|}
\hline $\begin{array}{c}\text { Type of } \\
\text { Congenital defect }\end{array}$ & $\begin{array}{l}\text { No. of cases } \\
\text { out of } 182\end{array}$ & $\begin{array}{c}\text { Percentage } \\
\%\end{array}$ \\
\hline Cardiovascular & 39 & 21.4 \\
\hline Respiratory & 3 & 1.6 \\
\hline Cerebrovascular & 14 & 7.7 \\
\hline Musculoskeletal & 23 & 12.6 \\
\hline Renal & 8 & 4.4 \\
\hline Urogenital & 22 & 12.1 \\
\hline Anorectal & 14 & 7.7 \\
\hline Gastrointestinal & 24 & 13.2 \\
\hline (Combination of anomalies) mixed & 35 & 19.2 \\
\hline $\begin{array}{l}\text { Total } \\
\end{array}$ & 182 & 100.0 \\
\hline
\end{tabular}

The total 182 cases studied were classified depending on the system to which they belonged and showed in Table $1.9^{9}$ It was seen that cardiovascular cases (39 cases) were the most common which was $21.4 \%$ out of the 182 cases.

\begin{tabular}{|c|c|c|}
\hline $\begin{array}{c}\text { Presence of } \\
\text { Consanguinity }\end{array}$ & $\begin{array}{c}\text { No. } \\
\text { of cases }\end{array}$ & $\begin{array}{c}\text { Percentage } \\
\mathbf{\%}\end{array}$ \\
\hline Yes & 48 & 26.4 \\
\hline No & 134 & 73.6 \\
\hline Total & $\mathbf{1 8 2}$ & $\mathbf{1 0 0 . 0}$ \\
\hline $\begin{array}{c}\text { Table 2: Comparison of Consanguinity and } \\
\text { occurrence of congenital defect }\end{array}$ \\
\hline
\end{tabular}

Table 2 shows that 48 cases of all 182 cases were born to consanguineously married parents which was $26.4 \%$ against 134 cases which were born to non-consanguineously married parents which was $73.6 \%$.

\begin{tabular}{|c|c|c|}
\hline $\begin{array}{c}\text { Degree of } \\
\text { Consanguinity }\end{array}$ & $\begin{array}{c}\text { Total } \\
\text { No. of cases }\end{array}$ & $\begin{array}{c}\text { Percentage } \\
\mathbf{\%}\end{array}$ \\
\hline Degree one & 0 & 0 \\
\hline Degree two & 21 & 11.5 \\
\hline Degree three & 27 & 14.8 \\
\hline Non consanguineous & 134 & 73.6 \\
\hline Total & $\mathbf{1 8 2}$ & $\mathbf{1 0 0 . 0}$ \\
\hline
\end{tabular}

Table 3: Degree of Consanguinity and congenital defect

Table 3 shows correlation of degree of consanguinity with Occurrence of congenital defects which shows zero case born to parents having consanguineous marriage of degree one, followed by 


\section{ORIGINAL ARTICLE}

21 cases and 27 cases out of total 182 cases born to parents having second and third degree of consanguineous marriage respectively.

Third degree cases/first cousin unions were most commonly occurring type of consanguineous marriage.

All the findings were statistically analysed and were found statistically non-significant.

The reason of findings coming statistically insignificant was lower sample size.

Hence there is scope for this study in future

Table 3 shows that Third degree cases / first cousin unions were most commonly occurring type of consanguineous marriage.

DISCUSSION: Births with congenital defects were commonly found to occur among normal births and the incidence calculated was $1.79 \%$ in the present study.

Comparison of type of Congenital Defect $(n=182)$ : In the present study we have classified all the anomalous cases according to the system and found that cardiovascular anomalies were the most common type. For discussion particularly with Z. Mosayebi and A.H. Movahedian ${ }^{10}$ study we have included Diaphragmatic hernia in gastrointestinal group which was originally included in musculoskeletal group in present study.

Also urogenital anomalies were grouped along with renal anomalies and labeled as Genitourinary anomalies and Ano-rectal anomalies were included in Gastrointestinal system itself. Hence now present study shows Gastrointestinal cases (44 cases) as the most common type 24.17\%, followed by cardiovascular cases (39) the second common which comes to $21.4 \%$.

Z. Mosayebi and A.H. Movahedian 10 in 2007 stated in his study that of all 109 congenital malformations studied, Genitourinary system cases were most commonly occurring $32.1 \%$ of all 109 cases, followed by musculoskeletal cases 24 cases in $22 \%$ and cardiovascular cases 16 cases in $14.7 \%$ shown in table 4.

This finding did not match with finding of present study.

\begin{tabular}{|c|c|c|c|c|c|}
\hline $\begin{array}{c}\text { Sl. } \\
\text { No. }\end{array}$ & $\begin{array}{c}\text { Type of } \\
\text { Congenital } \\
\text { defect }\end{array}$ & $\begin{array}{c}\text { No. of cases } \\
\mathbf{n = 1 0 9} \\
\text { Z. Mosayebi }{ }^{\mathbf{1 0}} \text { study }\end{array}$ & $\begin{array}{c}\text { \% } \\
\text { Z.Mosayebi10 } \\
\text { study }\end{array}$ & $\begin{array}{c}\text { No. of cases } \\
\text { n=182, Present } \\
\text { study }\end{array}$ & $\begin{array}{c}\text { \% } \\
\text { Present } \\
\text { study }\end{array}$ \\
\hline 1 & Genitourinary & 35 & 32.1 & 30 & 16.4 \\
\hline 2 & Musculoskeletal & 24 & 22.0 & 23 & 12.6 \\
\hline 3 & Cardiovascular & 16 & 14.7 & 39 & 21.4 \\
\hline 4 & Gastrointestinal & 7 & 6.4 & 44 & 24.17 \\
\hline 5 & Central nervous system & 6 & 5.5 & 14 & 7.7 \\
\hline 6 & Eye and ear defects & 5 & 4.6 & 0 & 0 \\
\hline 7 & Chromosomal defects & 2 & 1.8 & 6 & 3.29 \\
\hline 8 & Cutaneous defects & 1 & 0.9 & 0 & 0 \\
\hline 9 & Multiple defects & 13 & 12.0 & 35 & 19.2 \\
\hline \multicolumn{7}{|c|}{ Total } & $\mathbf{1 0 9}$ & $\mathbf{1 0 0}$ & $\mathbf{1 8 2}$ & $\mathbf{1 0 0}$ \\
\hline \multicolumn{7}{|c|}{ Table 4: Shows comparison of present study findings with Z.Mosayabi10 study } \\
\hline
\end{tabular}




\section{ORIGINAL ARTICLE}

\section{Comparison of Subtype of Congenital Defect:}

\begin{tabular}{|c|c|c|c|c|c|c|c|}
\hline $\begin{array}{c}\text { Sl. } \\
\text { No. }\end{array}$ & $\begin{array}{c}\text { Type of } \\
\text { congenital } \\
\text { defect }\end{array}$ & $\begin{array}{c}\text { Most } \\
\text { common } \\
\text { subtype Z. } \\
\text { Mosayebi10 } \\
\text { study }\end{array}$ & $\begin{array}{c}\text { No. of } \\
\text { cases Z. } \\
\text { Mosayebi10 } \\
\text { study }\end{array}$ & $\begin{array}{c}\text { \% Out of } \\
\mathbf{1 0 9} \text { cases } \\
\text { Z. } \\
\text { Mosayebi10 } \\
\text { study }\end{array}$ & $\begin{array}{c}\text { Most } \\
\text { common } \\
\text { subtype } \\
\text { Present } \\
\text { study }\end{array}$ & $\begin{array}{c}\text { No. of } \\
\text { cases } \\
\text { Present } \\
\text { study }\end{array}$ & $\begin{array}{c}\text { \% Out } \\
\text { of 182 } \\
\text { cases } \\
\text { Present } \\
\text { study }\end{array}$ \\
\hline 1 & Genitourinary & $\begin{array}{c}\text { Undescended } \\
\text { testes }\end{array}$ & 17 & 15.0 & Hypospadias & 7 & 3.84 \\
\hline 2 & Musculoskeletal & $\begin{array}{c}\text { Metatarsus } \\
\text { adductus } \\
\text { (limb defects) }\end{array}$ & 6 & 5.5 & Limb defects & 8 & 4.39 \\
\hline 3 & Cardiovascular & VSD & 5 & 4.7 & ASD & 18 & 9.89 \\
\hline 4 & Gastrointestinal & $\begin{array}{c}\text { Cleft } \\
\text { lip/palate }\end{array}$ & 3 & 2.8 & Anal atresia & 9 & 4.94 \\
\hline 5 & Central nervous & Anencephaly & 2 & 1.9 & Hydrocephaly & 6 & 3.29 \\
\hline 6 & Eye and ear & $\begin{array}{c}\text { Periauricular } \\
\text { skin tag }\end{array}$ & 3 & 2.8 & None & None & None \\
\hline 7 & Multiple & Not specified & Not & Not & Not specified & Not & Not \\
specified & specified \\
\hline
\end{tabular}

Table 5: Shows comparison of present study findings with Z.Mosayabi ${ }^{10}$ study

These finding of Z.Mosayabi10 study matches with that of present only in musculoskeletal system group.

Comparison of Degree of Consanguinity with Occurrence of Anomalies and Occurrence of Consanguineous Marriages: Z. Mosayebi, A. H. Movahedian ${ }^{10}$ in 2007, P. S. Rao, S. G. Inbaraj, 11 in 1980, A. Nath, C Patil, V. A. Naik, ${ }^{12}$ in 2004, in their respective studies stated similar findings that majority of consanguineous marriages were between first cousins i.e., third degree relationship between the parents.

\begin{tabular}{|c|c|c|c|c|c|c|c|}
\hline \multirow[t]{2}{*}{$\begin{array}{l}\text { Degree of consanguinity } \\
\text { and no of cases in each } \\
\text { category. } \\
\text { Z. Mosayebi10 study }\end{array}$} & \multicolumn{6}{|c|}{$\begin{array}{c}\text { Congenital anomalies in } \\
\text { Consanguineous marriages }(n=768) \\
n=54, \text { Z. Mosayebi }{ }^{10} \text { study }\end{array}$} & \multirow{2}{*}{ 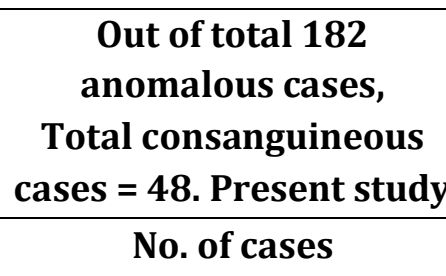 } \\
\hline & Major & $\%$ & Minor & $\%$ & Total & $\%$ & \\
\hline First degree $(n=0)$ & 0 & 0 & 0 & 0 & 0 & 0 & 0 \\
\hline $\begin{array}{l}\text { Second degree / uncle-niece } \\
\qquad(\mathrm{n}=291)\end{array}$ & 11 & 3.8 & 4 & 1.4 & 15 & 5.2 & 21 \\
\hline $\begin{array}{l}\text { Third degree/ first cousins } \\
\qquad(\mathrm{n}=477)\end{array}$ & 29 & 6.1 & 10 & 2.1 & 39 & 8.2 & 27 \\
\hline Total $=768$ & 40 & 5.2 & 14 & 1.8 & 54 & 7 & 48 \\
\hline
\end{tabular}




\section{ORIGINAL ARTICLE}

Z. Mosayebi, A. H. Movahedian, 10 in 2007 in their study stated that among the consanguineous group, 54(7.0\%) births had congenital anomalies, of which 39 cases were in firstcousin marriages and 15 cases were in second cousin or more distant relatives. This finding matches with present study.

\begin{tabular}{|c|c|c|c|c|c|c|}
\hline \multirow{2}{*}{$\begin{array}{c}\text { Degree of } \\
\text { consanguinity } \\
\text { P.S. S. Rao' }{ }^{11} \text { study }\end{array}$} & \multicolumn{2}{|c|}{$\begin{array}{l}\text { Rural, P. S. S. } \\
\text { Rao }^{11} \text { study }\end{array}$} & \multicolumn{2}{|c|}{$\begin{array}{l}\text { Urban, P. S. S. } \\
\text { Rao'}^{11} \text { study }\end{array}$} & \multirow{2}{*}{$\begin{array}{c}\text { Consanguinity } \\
\text { Present study }\end{array}$} & \multirow{2}{*}{$\begin{array}{c}\begin{array}{c}\text { Percentage } \\
100 \% \text { out of } \\
\text { total } 182 \text { cases }\end{array} \\
\%\end{array}$} \\
\hline & $\begin{array}{l}\text { No. of } \\
\text { cases }\end{array}$ & $\%$ & No. & $\%$ & & \\
\hline $\begin{array}{c}\text { Non- } \\
\text { consanguineous }\end{array}$ & 6169 & 53.1 & 6378 & 70.9 & 134 & 73.6 \\
\hline Consanguineous & 5459 & 46.9 & 2620 & 29.1 & 48 & 26.3 \\
\hline First degree & 0 & 0 & 0 & 0 & 0 & 0 \\
\hline $\begin{array}{l}\text { Second degree / } \\
\text { uncle niece and } \\
\text { aunt nephew }\end{array}$ & 1841 & 15.8 & 589 & 6.6 & 21 & 11.5 \\
\hline $\begin{array}{l}\text { Third degree/ first } \\
\text { cousins }\end{array}$ & 2886 & 24.8 & 1573 & 17.5 & 27 & 14.8 \\
\hline $\begin{array}{l}\text { Fourth degree } \\
\text { /First cousins once } \\
\text { removed }\end{array}$ & 393 & 3.4 & 265 & 3.0 & 0 & 0 \\
\hline $\begin{array}{c}\text { Fifth degree/ } \\
\text { second cousins }\end{array}$ & 269 & 2.3 & 143 & 1.6 & 0 & 0 \\
\hline $\begin{array}{l}\text { Beyond second } \\
\text { cousins }\end{array}$ & 70 & 0.6 & 50 & 0.5 & 0 & 0 \\
\hline
\end{tabular}

P.S. Rao, S.G. Inbaraj,11 in 1980 stated that in more than $80 \%$ of consanguineous marriages the partners were First cousins or more closely related i.e., third order relationship shown in table 7.

This finding matches with that of present study.

\begin{tabular}{|c|c|c|c|c|}
\hline $\begin{array}{c}\text { Degree of } \\
\text { consanguinity }\end{array}$ & $\begin{array}{c}\text { No. of cases } \\
\text { A. Nath et } \\
\text { al12 study }\end{array}$ & $\begin{array}{c}\text { Percentage \%, } \\
\text { A. Nath et al12 } \\
\text { study }\end{array}$ & $\begin{array}{c}\text { Present } \\
\text { study } \\
\text { No. of cases }\end{array}$ & $\begin{array}{c}\text { Present study } \\
\text { \% } \\
\text { Out of 48 } \\
\text { cases }\end{array}$ \\
\hline First degree & 0 & 0 & 0 & 0 \\
\hline $\begin{array}{c}\text { Second degree/uncle- } \\
\text { niece }\end{array}$ & 61 & 33.8 & 21 & 43.75 \\
\hline $\begin{array}{c}\text { Third degree / First } \\
\text { cousins }\end{array}$ & 98 & 54.4 & 27 & 56.25 \\
\hline Other distant relations & 21 & 11.6 & 0 & 0 \\
\hline Total cases & $\mathbf{1 8 0}$ & $\mathbf{1 0 0}$ & $\mathbf{4 8}$ & $\mathbf{1 0 0}$ \\
\hline
\end{tabular}

Table 8: Shows comparison of present study findings with A. Nath et al ${ }^{12}$ study

A. Nath et al,12 stated that majority of consanguineous marriages were between First cousins i.e., Third degree relationship in $54.44 \%$ shown in table 8 . This finding matches with present study. 


\section{ORIGINAL ARTICLE}

Comparison of Occurrence of Congenital Malformation with Presence of Consanguineous Marriages: Z. Mosayebi, A. H. Movahedian,10 in 2007, William schull2 in 1958, Naeimeb Tayebi and Katayon Tazdani, ${ }^{13}$ in 2010, M L Kulkarni, Mathew Kurian,14 in 1990, Khalid yunis and Reem SL Rafel,15 in 2008, Yunis k, Mumtaz G, 16 in 2006, Ranajit Chakraborty and Arvinda Chakraborty, 17 in 1977, Asha Bai P V, John TI,18 in 1981, AL-Kandari Y Y, Crews D E,19 in 2011, V. K. Jain et al,20 in Feb 1993 in their respective studies have stated that congenital malformations were occurring more common in consanguineous marriages than non-consanguineous marriages which matches present study findings.

\begin{tabular}{|c|c|c|c|c|c|c|c|c|}
\hline \multicolumn{9}{|c|}{$\begin{array}{l}\text { Prevalence of congenital malformation among } 3529 \text { neonates from } \\
\text { consanguineous and non-consanguineous marriages. } \\
\text { (Z. Mosayebi, A. H. Movahedian }{ }^{10} \text { study) }\end{array}$} \\
\hline \multirow{3}{*}{$\begin{array}{c}\text { Congenital } \\
\text { malformation }\end{array}$} & \multicolumn{6}{|c|}{ Consanguineous marriage $n=768$} & \multirow{2}{*}{\multicolumn{2}{|c|}{$\begin{array}{c}\text { Non- } \\
\text { consanguineous } \\
\text { marriage } \\
(n=2761)\end{array}$}} \\
\hline & \multicolumn{2}{|c|}{$\begin{array}{l}\text { First } \\
\text { cousin } \\
(n=477)\end{array}$} & \multicolumn{2}{|c|}{$\begin{array}{l}\text { Second cousin } \\
\text { or distant } \\
\text { relative } \\
(n=291)\end{array}$} & \multicolumn{2}{|c|}{$\begin{array}{c}\text { Total, } \\
\text { n = 768 }\end{array}$} & & \\
\hline & No & $\%$ & No & $\%$ & No & $\%$ & No & $\%$ \\
\hline Major & 29 & 6.1 & 11 & 3.8 & 40 & 5.2 & 23 & 0.8 \\
\hline Minor & 10 & 2.1 & 4 & 1.4 & 14 & 1.8 & 32 & 1.2 \\
\hline Total & 39 & 8.2 & 15 & 5.2 & 54 & 7.0 & 55 & 2.0 \\
\hline
\end{tabular}

Table 9 shows that Z. Mosayebi, A. H. Movahedian, ${ }^{10}$ in 2007 stated that congenital malformations were 3.5 times more common in consanguineous marriages than consanguineous marriages. The findings match with that of present study.

\begin{tabular}{|c|c|c|c|c|c|c|c|}
\hline \multirow[t]{2}{*}{$\begin{array}{l}\text { City William } \\
\text { schull }^{2} \text { study }\end{array}$} & \multicolumn{6}{|c|}{$\begin{array}{l}\text { Degree of consanguineous relationship among parents } \\
\text { W. Schull }{ }^{2} \text { study }\end{array}$} & \multirow[t]{2}{*}{ Total } \\
\hline & $\begin{array}{l}\text { Degree } \\
\text { one, } \\
\text { no. of } \\
\text { cases. }\end{array}$ & $\begin{array}{l}\text { Degree } \\
\text { second, } \\
\text { no. of } \\
\text { cases }\end{array}$ & 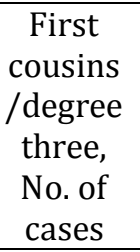 & $\begin{array}{c}1 \frac{1 / 2}{2} \\
\text { cousins/degree } \\
\text { four no. of } \\
\text { cases }\end{array}$ & $\begin{array}{c}\text { Second } \\
\text { cousins/ } \\
\text { fifth } \\
\text { degree } \\
\text { No. of } \\
\text { cases } \\
\end{array}$ & $\begin{array}{l}\text { Unrelated / non- } \\
\text { consansanguinity } \\
\text { No. of cases }\end{array}$ & \\
\hline Hiroshima & 0 & 0 & 936 & 313 & 384 & 26,012 & 27645 \\
\hline Kure & 0 & 0 & 318 & 113 & 140 & 7544 & 8115 \\
\hline Nagasaki & 0 & 0 & 1592 & 412 & 637 & 30240 & 32881 \\
\hline Total & 0 & 0 & 2846 & 838 & 1161 & 63796 & 68641 \\
\hline $\begin{array}{c}\text { Present study } \\
\text { Consanguineous } \\
n=48\end{array}$ & 0 & 21 & 27 & 0 & 0 & 0 & 48 \\
\hline $\begin{array}{c}\text { Present study } \\
\text { Nonconsanguineous } \\
n=134\end{array}$ & - & - & - & - & - & 134 & 134 \\
\hline
\end{tabular}




\section{ORIGINAL ARTICLE}

This table shows distribution of major congenital anomalies by consanguinity and city.

William schull, ${ }^{2}$ in 1958 stated in his study stated that frequency of infants with major congenital defects increases significantly with increasing level of (inbreeding) consanguineous relationship shown in Table 10.

Hence findings are similar to present study.

\begin{tabular}{|c|c|c|c|c|}
\hline \multirow{3}{*}{$\begin{array}{l}\text { Total no of congenital } \\
\text { defects in Naeimeh } \\
\text { Tayebi } 13 \text { study. } \\
\text { N= 45(3.76\%) }\end{array}$} & \multicolumn{4}{|c|}{ Total cases studied in Naeimeh Tayebi ${ }^{13}$ study, $n=1195(100 \%)$} \\
\hline & \multicolumn{2}{|c|}{$\begin{array}{l}\text { Cases from consanguineous } \\
\text { marriages } n=300(25 \%)\end{array}$} & \multicolumn{2}{|c|}{$\begin{array}{c}\text { Cases from non-consanguineous } \\
\text { marriages } n=895(75 \%)\end{array}$} \\
\hline & $\begin{array}{l}\text { No. of } \\
\text { anomalies }\end{array}$ & $\%$ of total births & No. of anomalies & $\begin{array}{l}\% \text { of } \\
\text { total } \\
\text { births }\end{array}$ \\
\hline \multirow[t]{2}{*}{$\begin{array}{c}\text { Total, } \mathrm{n}=45, \\
3.76 \% . \text { Naeimeh } \\
\text { Tayebi study. }\end{array}$} & 34 & 2.8 & 11 & $0.9 \%$ \\
\hline & $\begin{array}{c}\text { Consanguineous } \\
\text { cases, in } \\
\text { present study } \\
\end{array}$ & $\%$ & $\begin{array}{l}\text { Non-consanguineous } \\
\text { cases, in present study }\end{array}$ & $\%$ \\
\hline $\begin{array}{c}\text { Total anomalies } \\
\text { studied in present } \\
\text { study, } n=182,100 \%\end{array}$ & 48 & 26.4 & 134 & 74.6 \\
\hline
\end{tabular}

Table 11: Shows comparison of present study findings with Naeimeh Tayebi ${ }^{13}$ study

Table 11 shows that Naeimeb Tayebi and Katayon Tazdani ${ }^{13}$ in 2010 in their study done in 1195 newborns, stated that rate of congenital defect was higher in consanguineous $(2.8 \%)$ than that in non- consanguineous(0.9\%) marriages.

\begin{tabular}{|c|c|c|c|c|}
\hline \multirow{3}{*}{$\begin{array}{l}\text { Total no. of } \\
\text { malformations found } \\
\text { in } 3700 \text { births, } \\
n=146, \\
\text { Kulkarni M. L, Mathew } \\
\text { Khurian }{ }^{14} \text { study }\end{array}$} & \multicolumn{4}{|c|}{$\begin{array}{l}\text { Total no. of live and still births studied, } \\
\text { n = } 3700(100 \%) \text { Kulkarni M. L, Mathew Khurian }{ }^{14} \text { study }^{-} \text {(10) }\end{array}$} \\
\hline & \multicolumn{2}{|c|}{$\begin{array}{c}\text { Kulkarni M. L, Mathew } \\
\text { Khurian }{ }^{14} \text { study } \\
\text { Consanguineous cases, } \\
\text { n=999 }(27 \%)\end{array}$} & \multicolumn{2}{|c|}{$\begin{array}{c}\text { Kulkarni M. L, Mathew } \\
\text { Khurian }^{14} \text { study } \\
\text { Non-consanguineous cases, n= } \\
2731(73.81 \%)\end{array}$} \\
\hline & $\begin{array}{l}\text { No. of } \\
\text { cases }\end{array}$ & $\begin{array}{c}\% \text { out of total } \\
\text { anomalies i.e } \\
146\end{array}$ & $\begin{array}{l}\text { No. } \\
\text { of } \\
\text { cases }\end{array}$ & $\begin{array}{c}\% \text { out of total } \\
\text { anomalies i.e } \\
146\end{array}$ \\
\hline $\begin{array}{c}\text { Total cases = 146, } \\
\text { 100\% Kulkarni M.L, } \\
\text { Mathew Khurian }{ }^{15} \\
\text { study }\end{array}$ & 80 & 54.79 & 66 & 45.20 \\
\hline $\begin{array}{c}\text { Present study } \\
\text { Total anomalies } \\
\text { studied, } \mathrm{n}=182,100 \%\end{array}$ & 48 & 26.4 & 134 & 74.6 \\
\hline
\end{tabular}




\section{ORIGINAL ARTICLE}

Table 12 shows that M L Kulkarni, Mathew Kurian,14 in 1990 also stated that congenital anomalies were more common in consanguineous marriages. Their findings match with that of present study.

Khalid yunis, Reem SLRafel, ${ }^{15}$ in 2008 stated in their article that most common form of consanguineous union was between first cousins i.e., third degree relationship.

Yunis K and Mumtaz G,16 in their case-control trial studied 173 newborns having one or more congenital heart disease admitted to the Neonatal Intensive Care Units of participating hospitals during 3-year period from January 1, 2000 to December 31, 2002 and compared them with controls consisting of a random sample of 865 new borns without a congenital heart disease admitted to the NICU during the same period and found that first cousin consanguinity is significantly associated with an increased risk of congenital heart disease.

Infants born to first cousin marriages had a 1.8 times higher risk of having a congenital heart disease diagnosed at birth compared to those born to unrelated parents.

Ranajit Chakraborty and Aravinda Chakravarti,17 in 1977 in their study stated that the incidence of major congenital defects was significantly higher among the inbred offspring $(1.34 \%)$ as compared to that among non-inbred ones (0.81\%).

Asha Bai P V, John TJ, Subramaniam VR,18 in 1981 in their study stated that the number of pregnancies and live births were higher in consanguineous than in non -consanguineous unions. Although the intrauterine wastage showed no significant difference between the 2 groups, extrauterine loss of life, especially the death rate of children, was higher in the consanguineous marriages.

The frequency of developmental anomalies was significantly more frequent among the children of consanguineous parents.

Al-Kandari YY and Crews DE,19 in 2011 studied a total of 9104 married Kuwaiti females aged 15-79 years from different backgrounds at ten primary health care centres from six governorates in Kuwait and Data collected using a questionnaire and analysed with chi-squared tests which indicated that the frequency of congenital disabilities in the offspring of couples from consanguineous marriages was higher than that in the offspring of non-consanguineous marriages. First-cousin marriages have the highest frequency of congenital disabilities compared with other kinds of marriages.

V. K. Jain and P. Nalini ${ }^{20}$ in February 1993 in a study undertaken in Jawaharlal Institute of Postgraduate Medical Education and Research, Pondicherry, South India among four hundred children with existing congenital developmental disorders which were studied with regard to their consanguineous parentage and compared with 1,000 randomly selected patients attending the paediatric outpatient department.

There was a significantly higher prevalence of consanguinity in the study group $(\mathrm{p}<0.001)$ and greater frequency in rural areas. The common types of consanguineous marriages were between first cousins (50.6\%) and uncle and niece (42.4\%).

\section{SUGGESTIONS FOR FUTURE:}

1. The observations from references and present study stress the need for communicating the deleterious effects of inbreeding to the public through regular health education.

2. Increasing awareness among the public of the deleterious effects of consanguinity is a simple prevention strategy must be taken into account for genetic counselling. 


\section{ORIGINAL ARTICLE}

3. In case of pregnancy with consanguineous parents, recommendations are:

a) Compulsory counselling to estimate the risk of foetal illness and information about possible examination possibilities.

b) An ultrasound scan at the gestational age of 11-14 weeks in order to measure nuchal translucency and an early malformation scan.

c) An ultrasound scan for malformations at the gestational age of 18-20 weeks.

d) An ultrasound scan especially in order to detect foetal heart malformations at the gestational age of 20-24 weeks.

\section{CONCLUSIONS:}

1. Births with congenital defects were commonly occurring among normal births and the incidence calculated was $1.79 \%$ in the present study.

2. Cardiovascular defects were most common type of defects.

3. Third degree cases/First cousin unions were most commonly occurring type of consanguineous marriage.

4. Congenital defects were occurring more commonly in consanguineous unions than nonconsanguineous unions.

\section{REFERENCES:}

1. A. H. Bittles. Endogamy, consanguinity and community genetics. Journal of Genetics, December 2002; vol. 81, issue no. 3, pg. 91-98.

2. William. j. Schull. Emperical risks in consanguineous marriages; sex ratio, malformation and viability, AmJ Hum Genet, 1958 September; vol. 10, issue 3, 294-343.

3. Consanguinity definition from (internet) available at en.wikipedia.org / wiki/ Consanguinity. $\mathrm{H}$. Bittles and M. L. Black. Consanguinity, human evolution, and complex diseases. Proc Natl Acad Sci. U S A. 2010 January 26; 107(suppl_1): 1779-1786.

4. Bernadette Modell and Aamra Darr. Genetic counselling and customary consanguineous marriage. Nature reviews/ genetics, march 2002; vol. 3, 225- 229.

5. Mónica Rittler, Rosa Liascovich, Jorge López-Camelo, Eduardo E. Castilla. Parental consanguinity in specific types of congenital anomalies, American Journal of Medical Genetics, 22 July 2001; Vol. 102, Issue 1, pages 36-43.

6. Proband (internet) available at en.wikipedia.org/wiki/ Proband.

7. Harpar. P. Textbook of Practicle Genetic Counseling. Chapter 9, Special Problems In Genetic Counseling, Edition 4, 124,125.

8. Richard. E. Behrman et al. Nelson textbook of Pediatrics. 17th edition, Jun 2007; published at Philadelphia, PA; Elsevier/Saunders, 2011.

9. Z. Mosayebi and A. H. Movahedian. Pattern of congenital malformations in consanguineous versus non-consanguineous marriages in Kashan, Islamic Republic of Iran. Eastern Mediterranean health journal, 2007; vol. 13, No.4, 869-875.

10. P. S. Rao, S.G. Inbaraj. Inbreeding effects on fetal growth and development. Journal of medical genetics. 1980; 17, 27-33.

11. A. Nath, C. Patil, V. A. Naik. Prevalence of Consanguineous Marriages in a Rural Community and Its Effect on Pregnancy Outcome. Indian Journal of Community Medicine, 2004 Jan- Mar; Vol. 29, No. 1. 


\section{ORIGINAL ARTICLE}

12. Naeimeh Tayebi, Katayon Yazdani, Nazila Naghshin. The Prevalence of Congenital Malformations and its Correlation with Consanguineous Marriages, Oman Medical Journal 2010 Jan; Volume 25, Issue 1, 37-40.

13. M. L. Kulkarni and M Kurian. Consanguinity and its effect on fetal growth and development; a south Indian study. J. med. genet, 1990; 27: 348-352.

14. Yunis K, Reem El Rafei, and Ghina Mumtaz. Consanguinity: Perinatal Outcomes and Prevention - A View from the Middle East, Article International Perspectives Feb. 2008; Neoreviews vol. 9. No. 2, 59-64.

15. Yunis Khalid, Mumtaz Ghina, Bitar Fadi, Chamseddine Fadi, Kassar May, Rashkidi Joseph, Ghaith Makhoul, Tamim Hala. Consanguineous Marriage and Congenital Heart Defects- A Case-Control Study in the Neonatal Period. American Journal of Medical Genetics Part A (2006) Jul. 15; 140(14); 1524-30.

16. Ranajit Chakraborty and Arvinda Chakravarty. On consanguineous marriages and genetic load.human genetics, 1977; vol. 36. Number 1, 47-54.

17. Asha Bai P V, John T. J, Subramaniam V.R. Reproductive wastage and developmental disorders in relation to consanguinity in south India. Trop. Gregor. Med 1981 Sep; 33(3), 275-80.

18. Al-Kandari YY, Crews DE. The effect of consanguinity on congenital disabilities in the kuwaiti population. Journal of Biosocial Science / Volume 43 / Issue 01 / January 2011; pp 65-73.

19. V. K. Jain, P. Nalini, Chandra R, Srinivasan S. Congenital malformations, reproductive wastage and consanguineous mating. Aust. N Z J Obstet Gynaecol. 1993 Feb; 33(1): 33-6.

\section{AUTHORS:}

1. Sundip Hemant Charmode

\section{PARTICULARS OF CONTRIBUTORS:}

1. Assistant Professor, Department of Anatomy, ESIC Medical College, Paravoor Road, Parippally, Kollam.

FINANCIAL OR OTHER COMPETING INTERESTS: None

\section{NAME ADDRESS EMAIL ID OF THE} CORRESPONDING AUTHOR:

Dr. Sundip Hemant Charmode, ESIC Medical College,

Paravoor Road, Parippally, Kollam-691574.

E-mail: sundip.charmode@yahoo.com

Date of Submission: 05/05/2015.

Date of Peer Review: 06/05/2015.

Date of Acceptance: 20/05/2015.

Date of Publishing: 26/05/2015. 